\title{
CHANGES OF BLOOD OXYGEN AFFINITY IN FANSIDAR-TREATED MICE INFECTED WITH PLASMODIUM BERGHEI
}

\author{
Atsushi Hioki AND HiRoshi OHtomo \\ Received November 10 1986/Accepted February 151987
}

\begin{abstract}
Changes of blood oxygen affinity in mice infected with Plasmodium berghei and treated with Fansidar $(20 \mathrm{mg} / \mathrm{kg}$ body weight sulfadoxine and $1 \mathrm{mg} / \mathrm{kg}$ body weight pyrimethamine orally) were observed. When 5 -weeks-old male mice were inoculated intraperitoneally with $10^{7}$ of $P$. berghei-infected red cells and treated with Fansidar on day 5 after inoculation, 67\% of the animals survived. Parasitemia decreased and abnormal values of glycolytic intermediates began to recover following Fansidar administration. However, hemoglobin content still decreased on day 2 of the treatment, and methemoglobin fraction increased on days 1, 2, 3 and 4 . Blood oxygen affinity increased markedly on days 2 and 3. These findings suggested aggravation of the host's hypoxic state on day 2 of the treatment.
\end{abstract}

\section{INTRODUCTION}

Malaria is relatively easy to cure if treated properly on the basis of early diagnosis. However, delay in the onset of treatment, especially for falciparum malaria, causes a higher level of parasitemia, severe complications and sometimes death of the host. Furthermore, death of patients with markedly decreased parasitemia following antimalarial treatment have been reported (Devakul et al., 1966; Stone et al., 1972), but its mechanism is not yet understood.

The pathophysiology of falciparum malaria is considerably complex. Most organs are reported to be involved in this infection, and many factors contributing to dysfunction of these organs have been enumerated (WHO, 1980; Bruce-Chwatt, 1980). Tissue hypoxia is thought to be one of the main causes of severe complications (Hall, 1977). We have already reported that the decrease in blood oxygen affinity in the course of Plasmodium berghei infection in mice may be a compensatory mechanism for tissue hypoxia resulting from malaria (Ohtomo et al., 1982).

In this study, we intended to clarify the effect of treatment on blood oxygen affinity in $P$. berghei infected mice. We used Fansidar as an antimalarial drug because it is effective in a single dose and has clear action of only blocking the 2 sequential stages of the pathway leading to tetrahydrofolate (Donno, 1974; Weidekamm et al., 1982).

\section{Materials AND Methods}

Male mice of ddY strain, 5 weeks old, were used in this study. Plasmodium berghei, strain NK65, has been maintained in our laboratory by injecting a dilute suspension of infected blood

Department of Parasitology, Gifu University School of Medicine, 40 Tsukasa-machi, Gifu 500, Japan 
into mice from the corresponding strain every week. Blood was collected from an infected mouse by cardiac puncture using heparin as an anticoagulant, diluted with saline to yield $1 \times 10^{8}$ infected red cells $/ \mathrm{ml}$, and $0.1 \mathrm{~m} l$ of this suspension was injected intraperitoneally. The time interval between exsanguination and inoculation was less than 1 hour. Mice were kept at 24$26^{\circ} \mathrm{C}$ and $40-60 \%$ humidity and exposed to a photoperiod of $12 \mathrm{~h}$ light and $12 \mathrm{~h}$ darkness. Under these conditions, mice died 6-7 days after inoculation.

In the initial trials, designed to evaluate the time of treatment, 3 groups of 6 mice each were infected. Fansidar (F. Hoffmann-La Roche, Switzerland) was dissolved in distilled water and administered orally ( $1 \mathrm{mg}$ pyrimethamine and $20 \mathrm{mg}$ sulfadoxine $/ \mathrm{kg}$ body weight) on day 4 after inoculation to group 1, day 5 to group 2, and day 6 to group 3, respectively (Ferraroni and Speer, 1982). The course of the infection was followed by determining parasitemia and reticulocyte count daily first by new methylene blue- followed by Giemsa-stained blood smears from the tail vein.

In the present study, the mice were inoculated with $P$. berghei and treated with Fansidar on day 5 of infection. Eleven mice each were anesthetized with pentobarbital sodium $(50 \mathrm{mg} / \mathrm{kg}$ body weight intraperitoneally) on days $0,1,2,3,4,5$ or 6 after Fansidar treatment, and whole blood was collected into heparinized syringes from the carotid artery within 5 minutes. Parasitemia was determined on Giemsa-stained thin blood film. Total hemoglobin concentration was measured by the cyanmethemoglobin method and methemoglobin fraction according to the KCN addition method (International Committee for Standardization in Haematology, 1978; Zwart et al., 1981). Hematocrit was determined by means of a microhematocrit centrifuge. Oxygen equilibrium curve (OEC) of whole blood was measured at $37^{\circ} \mathrm{C}$ on a Hem-O-Scan analyzer (Aminco Co., USA), and blood oxygen affinity was expressed as the half-saturation pressure values at actual $\mathrm{pH}$ in vivo $\left(\mathrm{P}_{50}\right.$ act $\left.\mathrm{pH}\right)$. The Hill-coefficient $n$ was obtained by linear regression analysis of $\log [\mathrm{y} /(1-\mathrm{y})]$ vs. $\log \mathrm{Po}_{2}$, where $\mathrm{y}$ is $\mathrm{O}_{2}$ saturation for the data points of the $\mathrm{OEC}\left(\mathrm{O}_{2}\right.$ saturation $=30,35,40,45,50,55,60,65$ and $70 \%$ ). Whole blood $\mathrm{pH}$ was measured immediately at $37^{\circ} \mathrm{C}$ with a glass electrode. 2, 3-Diphosphoglycerate concentration was determined according to a modified kit (No. 148334; Boehringer Mannheim GmbH, F. R. Germany) of the enzymatic end-point method. Blood adenosine triphosphate (ATP) concentration was determined by means of the luciferase reaction with a CHEM-GLOW (Aminco Co.) (Chapman et al., 1971). Concentrations of blood glucose, pyruvate and lactate were determined according to a modified kit (Nos. 124028, 124982 and 124842; Boehringer Mannheim GmbH).

\section{RESULTS}

Fansidar treatment on day 6 of Plasmodium berghei inoculation resulted in 100\% mortality in mice 1-2 days after treatment. Sixty-seven percent of mice treated on day 5 and $100 \%$ of those on day 4 survived more than 10 days after treatment (Table 1). Parasitemia decreased following treatment compared with increasing in untreated subjects. Simultaneously, polychromatophilic erythrocytes in the peripheral blood began to increase and significant reticulocytosis was observed from day 2 after treatment $(\mathrm{p}<0.05)$. When Fansidar was given on day 5 , most of the parasites appeared to have degenerated on day 2 of treatment, and parasitemia became undetectable on day 4. Reticulocyte count reached its peak on day 5 after treatment, although uninfected controls remained low (Table 1).

Parasitemia of mice sacrificed for measurement (Table 2) were much the same as above. 
Table 1 Time course of changes in parasitemia and reticulocytosis of mice treated with Fansidar 4 and 5 days after Plasmodium berghei inoculation

\begin{tabular}{|c|c|c|c|c|c|c|c|c|c|c|}
\hline \multirow{2}{*}{$\begin{array}{c}\text { Day of Fansidar } \\
\text { treatment }\end{array}$} & & \multicolumn{9}{|c|}{ Days after Fansidar treatment } \\
\hline & & 0 & 1 & 2 & 3 & 4 & 5 & 6 & 8 & 10 \\
\hline \multirow{3}{*}{$\begin{array}{l}4 \text { days after } \\
\text { inoculation }\end{array}$} & No. of surviving mice & 6 & 6 & 6 & 6 & 6 & 6 & 6 & 6 & 6 \\
\hline & Parasitemia $(\%)$ & $\begin{array}{r}26.4 \\
\pm 5.0\end{array}$ & $\begin{array}{r}7.5 \\
\pm 1.6\end{array}$ & $\begin{array}{r}1.7 \\
\pm 0.5\end{array}$ & $\begin{array}{r}0 \\
\pm 0\end{array}$ & $\begin{array}{r}0 \\
\pm 0\end{array}$ & $\begin{array}{r}0 \\
\pm 0\end{array}$ & $\begin{array}{r}0 \\
\pm 0\end{array}$ & $\begin{array}{r}0 \\
\pm 0\end{array}$ & $\begin{array}{r}0 \\
\pm 0\end{array}$ \\
\hline & Reticulocyte (\%) & $\begin{array}{r}0.5 \\
\pm 0.2\end{array}$ & $\begin{array}{r}3.4 \\
\pm 0.6\end{array}$ & $\begin{array}{r}6.0 \\
\pm 1.3\end{array}$ & $\begin{array}{r}10.0 \\
\pm 1.3\end{array}$ & $\begin{array}{r}23.7 \\
\pm 6.0\end{array}$ & $\begin{array}{r}28.5 \\
\pm 4.2\end{array}$ & $\begin{array}{r}19.6 \\
\pm 2.9\end{array}$ & $\begin{array}{r}15.9 \\
\pm 1.3\end{array}$ & $\begin{array}{r}11.7 \\
\pm 2.0\end{array}$ \\
\hline \multirow{3}{*}{$\begin{array}{l}5 \text { days after } \\
\text { inoculation }\end{array}$} & No. of su & 6 & 4 & 4 & 4 & 4 & 4 & 4 & 4 & 4 \\
\hline & Parasitemia $(\%)$ & $\begin{array}{r}62.7 \\
\pm 2.2\end{array}$ & $\begin{array}{r}41.7 \\
\pm 5.8\end{array}$ & $\begin{array}{r}10.7 \\
\pm 2.9\end{array}$ & $\begin{array}{r}2.4 \\
\pm 1.0\end{array}$ & $\begin{array}{r}0 \\
\pm 0\end{array}$ & $\begin{array}{r}0 \\
\pm 0\end{array}$ & $\begin{array}{r}0 \\
\pm 0\end{array}$ & $\begin{array}{r}0 \\
\pm 0\end{array}$ & $\begin{array}{r}0 \\
\pm 0\end{array}$ \\
\hline & Reticulocyte (\%) & $\begin{array}{r}0.4 \\
\pm 0.1\end{array}$ & $\begin{array}{r}4.1 \\
\pm 0.5\end{array}$ & $\begin{array}{r}15.6 \\
\pm 1.6\end{array}$ & $\begin{array}{r}17.9 \\
\pm 3.3\end{array}$ & $\begin{array}{r}29.1 \\
\pm 4.1\end{array}$ & $\begin{array}{r}35.2 \\
\pm 6.4\end{array}$ & $\begin{array}{r}31.0 \\
\pm 3.5\end{array}$ & $\begin{array}{r}20.9 \\
\pm 4.2\end{array}$ & $\begin{array}{r}8.9 \\
\pm 0.2\end{array}$ \\
\hline \multirow[b]{2}{*}{$\begin{array}{l}\text { Uninfected } \\
\text { controls }\end{array}$} & No. of mice & 6 & 6 & 6 & 6 & 6 & 6 & 6 & 6 & 6 \\
\hline & Reticulocyte (\%) & $\begin{array}{r}2.8 \\
\pm 0.1\end{array}$ & $\begin{array}{r}2.9 \\
\pm 0.2\end{array}$ & $\begin{array}{r}2.6 \\
\pm 0.2\end{array}$ & $\begin{array}{r}2.7 \\
\pm 0.3\end{array}$ & $\begin{array}{r}2.9 \\
\pm 0.3\end{array}$ & $\begin{array}{r}2.7 \\
\pm 0.3\end{array}$ & $\begin{array}{r}2.6 \\
\pm 0.2\end{array}$ & $\begin{array}{r}2.7 \\
\pm 0.3\end{array}$ & $\begin{array}{r}3.1 \\
\pm 0.4\end{array}$ \\
\hline \multirow{2}{*}{$\begin{array}{l}\text { Uninfected and } \\
\text { Fansidar treated } \\
\text { controls }\end{array}$} & No. of mice & 6 & 6 & 6 & 6 & 6 & 6 & 6 & 6 & 6 \\
\hline & Reticulocyte (\%) & $\begin{array}{r}2.9 \\
\pm 0.4\end{array}$ & $\begin{array}{r}3.2 \\
\pm 0.3\end{array}$ & $\begin{array}{r}2.7 \\
\pm 0.3\end{array}$ & $\begin{array}{r}3.2 \\
\pm 0.3\end{array}$ & $\begin{array}{r}2.6 \\
\pm 0.3\end{array}$ & $\begin{array}{r}2.9 \\
\pm 0.3\end{array}$ & $\begin{array}{r}2.7 \\
\pm 0.2\end{array}$ & $\begin{array}{r}2.9 \\
\pm 0.4\end{array}$ & $\begin{array}{r}2.9 \\
\pm 0.4\end{array}$ \\
\hline
\end{tabular}

Values are means $\pm \mathrm{SE}$ of surviving mice.

Table 2 Hematological data of mice infected with $P$. berghei and treated with Fansidar on day 5 of infection

\begin{tabular}{|c|c|c|c|c|c|c|c|c|c|}
\hline & \multicolumn{2}{|c|}{ Uninfected controls } & \multicolumn{7}{|c|}{ Days after Fansidar treatment } \\
\hline & $\begin{array}{c}\text { No } \\
\text { treatment }\end{array}$ & $\begin{array}{l}\text { Fansidar } \\
\text { treatment }\end{array}$ & 0 & 1 & 2 & 3 & 4 & 5 & 6 \\
\hline Parasitemia (\%) & - & - & $\begin{array}{r}65.5 \\
\pm 2.6\end{array}$ & $\begin{array}{r}43.7 \\
\pm 5.0\end{array}$ & $\begin{array}{r}12.6 \\
\pm 1.4\end{array}$ & $\begin{array}{r}1.5 \\
\pm 0.7\end{array}$ & $\begin{array}{r}0 \\
\pm 0\end{array}$ & $\begin{array}{r}0 \\
\pm 0\end{array}$ & $\begin{array}{r}0 \\
\pm 0\end{array}$ \\
\hline $\mathrm{Hb}(\mathrm{g} / \mathrm{dl})$ & $\begin{array}{r}12.8 \\
\pm 0.2\end{array}$ & $\begin{array}{r}12.7 \\
\pm 0.2\end{array}$ & $\begin{array}{r}7.2 \\
\pm 0.3\end{array}$ & $\begin{array}{r}7.4 \\
\pm 0.4\end{array}$ & $\begin{array}{r}4.6 \\
\pm 0.2\end{array}$ & $\begin{array}{r}5.7 \\
\pm 0.7\end{array}$ & $\begin{array}{r}6.5 \\
\pm 0.3\end{array}$ & $\begin{array}{r}7.6 \\
\pm 0.6\end{array}$ & $\begin{array}{r}9.9 \\
\pm 0.3\end{array}$ \\
\hline Ht $(\%)$ & $\begin{array}{r}40.5 \\
\pm 0.7\end{array}$ & $\begin{array}{r}40.8 \\
\pm 0.6\end{array}$ & $\begin{array}{r}25.7 \\
\pm 1.1\end{array}$ & $\begin{array}{r}25.4 \\
\pm 1.1\end{array}$ & $\begin{array}{r}16.9 \\
\pm 0.8\end{array}$ & $\begin{array}{r}20.6 \\
\pm 1.8\end{array}$ & $\begin{array}{r}25.6 \\
\pm 1.4\end{array}$ & $\begin{array}{r}28.4 \\
\pm 1.8\end{array}$ & $\begin{array}{r}36.6 \\
\pm 0.7\end{array}$ \\
\hline $\mathrm{MCHC}(\%)$ & $\begin{array}{r}31.7 \\
\pm 0.2\end{array}$ & $\begin{array}{r}31.2 \\
\pm 0.3\end{array}$ & $\begin{array}{r}27.9 \\
\pm 0.6\end{array}$ & $\begin{array}{r}29.2 \\
\pm 0.5\end{array}$ & $\begin{array}{r}27.4 \\
\pm 0.7\end{array}$ & $\begin{array}{r}27.2 \\
\pm 1.0\end{array}$ & $\begin{array}{r}25.7 \\
\pm 0.5\end{array}$ & $\begin{array}{r}26.9 \\
\pm 0.7\end{array}$ & $\begin{array}{r}27.1 \\
\pm 0.5\end{array}$ \\
\hline
\end{tabular}

Values are means $\pm \mathrm{SE}$ for 11 sacrificed mice each. $\mathrm{Hb}$, hemoglobin; $\mathrm{Ht}$, hematocrit;

$\mathrm{MCHC}$, mean corpuscular hemoglobin concentration.

Hemoglobin content and hematocrit decreased on day 2 of treatment and then increased from day 3 as summarized in Table 2. No significant changes were seen in the parameters of the uninfected controls after the administration of Fansidar. Methemoglobin fraction elevated on days $1(9.3 \pm 1.0 \%$, mean $\pm \mathrm{SE}, \mathrm{n}=6), 2(13.8 \pm 3.2 \%), 3(9.6 \pm 2.9 \%)$ and $4(13.6 \pm 2.3 \%)$ after treatment compared to days $0(5.4 \pm 0.9 \%), 5(5.9 \pm 1.8 \%)$ and $6(4.3 \pm 1.5 \%)$, and uninfected controls and uninfected-Fansidar-treated ones showed $0.8 \pm 0.1 \%$ and $0.9 \pm 0.1 \%$ respectively. 
Mean corpuscular hemoglobin concentration $(\mathrm{MCHC})$ remained lower from day 0 to day 6 compared to uninfected controls $(\mathrm{p}<0.01)$ and reached its lowest level on day 4. $\mathrm{P}_{50}$ act $\mathrm{pH}$, reflecting blood oxygen affinity, increased dramatically on day 1 of treatment compared to uninfected controls and day $0(\mathrm{p}<0.01)$. Then, it diminished on days 2 and $3(\mathrm{p}<0.001)$ (Table 3 ). Table 3 also presents the Hill's $n$ value reflecting the slope of the OEC, showing an increase after treatment $(\mathrm{p}<0.001)$. Changes in red cell 2, 3-DPG and ATP concentrations and in blood $\mathrm{pH}$ are also shown in Table 3. Red cell ATP concentration began to increase from day 1 of treatment and 2, 3-DPG from day 2. Although blood $\mathrm{pH}$ continued to be decreased on day 1 , it returned abruptly to within normal limits on day 2. Concentrations of glycolytic intermediates are summarized in Table 4. Blood glucose concentration, which had decreased on day 5 of infection to about one third of uninfected controls, began to increase after Fansidar treatment. In contrast, blood pyruvate and lactate concentrations increased after the infection and remained high up to day 1 of treatment but began to decrease from day 2 .

Table 3 Mean values and SE $(\mathrm{n}=11)$ of parameters measured in mice infected with $P$. berghei and treated with Fansidar on day 5 of infection

\begin{tabular}{|c|c|c|c|c|c|c|c|c|c|}
\hline & \multicolumn{2}{|c|}{ Uninfected controls } & \multicolumn{7}{|c|}{ Days after Fansidar treatment } \\
\hline & $\begin{array}{c}\text { No } \\
\text { treatment }\end{array}$ & $\begin{array}{l}\text { Fansidar } \\
\text { treatment }\end{array}$ & 0 & 1 & 2 & 3 & 4 & 5 & 6 \\
\hline $\mathrm{P}_{50}$ act $\mathrm{pH}$ (Torr) & $\begin{array}{r}40.0 \\
\pm 0.2\end{array}$ & $\begin{array}{r}41.0 \\
\pm 0.5\end{array}$ & $\begin{array}{r}52.7 \\
\pm 1.1\end{array}$ & $\begin{array}{r}61.5 \\
\pm 2.6\end{array}$ & $\begin{array}{r}47.8 \\
\pm 1.6\end{array}$ & $\begin{array}{r}43.8 \\
\pm 0.6\end{array}$ & $\begin{array}{r}42.4 \\
\pm 1.0\end{array}$ & $\begin{array}{r}43.3 \\
\pm 0.9\end{array}$ & $\begin{array}{r}44.4 \\
\pm 1.2\end{array}$ \\
\hline Hill's $n$ & $\begin{array}{r}3.02 \\
\pm 0.01\end{array}$ & $\begin{array}{r}2.99 \\
\pm 0.01\end{array}$ & $\begin{array}{r}2.87 \\
\pm 0.03\end{array}$ & $\begin{array}{r}3.03 \\
\pm 0.02\end{array}$ & $\begin{array}{r}3.21 \\
\pm 0.04\end{array}$ & $\begin{array}{r}3.25 \\
+0.03\end{array}$ & $\begin{array}{r}3.10 \\
\pm 0.05\end{array}$ & $\begin{array}{r}3.13 \\
\pm 0.03\end{array}$ & $\begin{array}{r}3.22 \\
\pm 0.08\end{array}$ \\
\hline $2,3-\mathrm{DPG}(\mu \mathrm{M} / \mathrm{gHb})$ & $\begin{array}{r}28.9 \\
\pm 1.0\end{array}$ & $\begin{array}{r}30.2 \\
\pm 1.2\end{array}$ & $\begin{array}{r}15.8 \\
\pm 2.5\end{array}$ & $\begin{array}{r}13.8 \\
\pm 2.0\end{array}$ & $\begin{array}{r}21.8 \\
\pm 1.5\end{array}$ & $\begin{array}{r}26.1 \\
\pm 0.8\end{array}$ & $\begin{array}{r}23.9 \\
\pm 1.2\end{array}$ & $\begin{array}{r}22.2 \\
\pm 1.0\end{array}$ & $\begin{array}{r}23.1 \\
\pm 1.0\end{array}$ \\
\hline $\operatorname{ATP}(\mu \mathrm{M} / \mathrm{gHb})$ & $\begin{array}{r}5.8 \\
\pm 0.1\end{array}$ & $\begin{array}{r}5.7 \\
\pm 0.1\end{array}$ & $\begin{array}{r}4.9 \\
+0.1\end{array}$ & $\begin{array}{r}6.4 \\
\pm 0.3\end{array}$ & $\begin{array}{r}8.2 \\
\pm 0.4\end{array}$ & $\begin{array}{r}9.3 \\
\pm 0.7\end{array}$ & $\begin{array}{r}10.6 \\
\pm 0.4\end{array}$ & $\begin{array}{r}9.4 \\
\pm 0.5\end{array}$ & $\begin{array}{r}9.0 \\
\pm 0.3\end{array}$ \\
\hline Blood pH & $\begin{array}{r}7.43 \\
\pm 0.01\end{array}$ & $\begin{array}{r}7.42 \\
\pm 0.01\end{array}$ & $\begin{array}{r}7.06 \\
\pm 0.04\end{array}$ & $\begin{array}{r}7.08 \\
\pm 0.06\end{array}$ & $\begin{array}{r}7.39 \\
\pm 0.01\end{array}$ & $\begin{array}{r}7.41 \\
\pm 0.01\end{array}$ & $\begin{array}{r}7.41 \\
\pm 0.01\end{array}$ & $\begin{array}{r}7.41 \\
\pm 0.01\end{array}$ & $\begin{array}{r}7.43 \\
\pm 0.01\end{array}$ \\
\hline
\end{tabular}

$\mathrm{P}_{50}$ act $\mathrm{pH}$, partial pressure of oxygen at $50 \%$ oxyhemoglobin saturation (actual $\mathrm{pH}$, temp $=37^{\circ} \mathrm{C}$ ); 2 ,

3-DPG, 2, 3-diphosphoglycerate. Hill's $n$ values are calculated by linear regression analysis of $\log$ [y/(1-y)] vs. $\log \mathrm{Po}_{2}$, where $\mathrm{y}$ is $\mathrm{O}_{2}$ saturation.

Table 4 Concentrations of glycolytic intermediates before and after treatment of $P$. berghei-infected mice with Fansidar on day 5 of infection

\begin{tabular}{|c|c|c|c|c|c|c|c|c|c|}
\hline & \multicolumn{2}{|c|}{ Uninfected controls } & \multicolumn{7}{|c|}{ Days after Fansidar treatment } \\
\hline & $\begin{array}{c}\text { No } \\
\text { treatment }\end{array}$ & $\begin{array}{l}\text { Fansidar } \\
\text { treatment }\end{array}$ & 0 & 1 & 2 & 3 & 4 & 5 & 6 \\
\hline Glucose $(\mathrm{mM} / \mathrm{l})$ & $\begin{array}{r}12.1 \\
\pm 0.5\end{array}$ & $\begin{array}{r}12.9 \\
\pm 0.4\end{array}$ & $\begin{array}{r}3.6 \\
\pm 0.4\end{array}$ & $\begin{array}{r}5.0 \\
\pm 1.3\end{array}$ & $\begin{array}{r}8.1 \\
\pm 0.6\end{array}$ & $\begin{array}{r}9.0 \\
\pm 0.7\end{array}$ & $\begin{array}{r}8.9 \\
\pm 0.5\end{array}$ & $\begin{array}{r}8.1 \\
\pm 0.5\end{array}$ & $\begin{array}{r}8.7 \\
\pm 0.4\end{array}$ \\
\hline Pyruvate $(\mathrm{mM} / l)$ & $\begin{array}{r}0.11 \\
\pm 0.01\end{array}$ & $\begin{array}{r}0.09 \\
\pm 0.01\end{array}$ & $\begin{array}{r}0.34 \\
\pm 0.02\end{array}$ & $\begin{array}{r}0.46 \\
\pm 0.04\end{array}$ & $\begin{array}{r}0.24 \\
\pm 0.04\end{array}$ & $\begin{array}{r}0.14 \\
\pm 0.03\end{array}$ & $\begin{array}{r}0.13 \\
\pm 0.01\end{array}$ & $\begin{array}{r}0.12 \\
\pm 0.02\end{array}$ & $\begin{array}{r}0.13 \\
\pm 0.02\end{array}$ \\
\hline Lactate $(\mathrm{mM} / \mathrm{l})$ & $\begin{array}{r}3.4 \\
\pm 0.3\end{array}$ & $\begin{array}{r}4.0 \\
\pm 0.2\end{array}$ & $\begin{array}{r}10.0 \\
\pm 0.4\end{array}$ & $\begin{array}{r}12.1 \\
\pm 0.8\end{array}$ & $\begin{array}{r}8.3 \\
\pm 0.4\end{array}$ & $\begin{array}{r}6.3 \\
\pm 0.9\end{array}$ & $\begin{array}{r}7.2 \\
\pm 1.3\end{array}$ & $\begin{array}{r}5.9 \\
\pm 1.8\end{array}$ & $\begin{array}{r}4.8 \\
\pm 0.4\end{array}$ \\
\hline
\end{tabular}

Values are means $\pm \mathrm{SE}$ for 6 sacrificed mice each. 


\section{DISCUSSION}

Plasmodium falciparum causes severe infection in humans, because it invades red cells of all ages and multiplies rapidly. If patients are not provided with rapid diagnosis and treatment, they may expire due to severe complications.

We have studied the pathophysiological significance of hypoxia in malaria using experimental animal models. The present study was designed to clarify more accurately the mechanism leading to death when treatment is delayed. We investigated blood oxygen transport in mice treated with Fansidar on day 5 after $P$. berghe $i$ inoculation, and $67 \%$ of the mice treated on day 5 survived compared with a $100 \%$ survival rate for those treated on day 4 in the initial study.

Hemoglobin concentration decreased on day 2 of Fansidar treatment although parasitemia decreased following treatment. Such a reduction in hemoglobin concentration after treatment against acute malarial infection has been widely accepted (Devakul et al., 1966; Abdalla $e t$ al., 1980). To make matters worse, in this situation, methemoglobin fraction increased after Fansidar treatment. It is suggested that the oxygen supply to the tissues decreased due to the presence of methemoglobin in the red cells which causes not only a loss of oxygen binding capacity in the blood but also a decrease in oxygen unloading from the bood (Darling and Roughton, 1942). $\mathrm{P}_{50}$ act $\mathrm{pH}$ markedly increased on day 1 of treatment and began to decrease from day 2, although it remained higher compared to uninfected controls. Such a decrease of affinity is an unfavorable change in the blood oxygen supply. In contrast, Hill's $n$, reflecting the slope of the OEC, increased after treatment. This change appears to be somewhat advantageous to blood oxygen transport. Considerisng the available hemoglobin content, however, the blood oxygen-supplying capacity seems to be lowest on day 2 of treatment. It is suggested that this might be one explanation for sudden death of falciparum malaria patients after parasitemia has decreased markedly following chemotherapy (Devakul et al., 1966; Stone et al., 1972).

Reticulocyte count began to increase following treatment. This may be a reaction of the body after successful treatment of an anemic situation, and also be due to the decrease in $P$. berghei which preferentially invades reticulocytes (Büngener, 1979). An increase in hemoglobin content followed this compensatory reticulocytosis, and anemia gradually vanished. A rapid increase in red cell 2, 3-DPG concentration after treatment may be due to a higher concentration of 2, 3-DPG in the increased younger erythrocytes (Mairbäurl et al., 1983).

Blood glucose concentration increased from day 1 of treatment, possibly resulting from inactivated glycolysis caused by the parasites subsequent to the decrease in parasitemia (Homewood, 1977; Homewood and Neame, 1983). However, blood pyruvate and lactate concentrations remained high on day 1 and began to decrease from day 2 . This may have been due to the parasites still present in the blood, and also partly to the inability of the host to reduce them because malaria causes reduction in renal microcirculatory flow, hypoxemia, tissue hypoxia and hepatic dysfunction (WHO, 1980; Hall, 1977). Lactate accumulation in the tissue, especially in the brain which is protected by a blood-brain barrier (Pardridge and Oldendorf, 1977), may persist longer than in the blood following treatment. Although blood lactate concentration still remained high on day 2, blood $\mathrm{pH}$ increased to 7.39. It is suggested that the carbonic acidbicarbonate buffer system may play an important role in normalizing blood $\mathrm{pH}$. Such an increase in $\mathrm{pH}$ may help to account the decrease in $\mathrm{P}_{50}$ act $\mathrm{pH}$ (Bellingham et al., 1971). It should be borne in mind that correction of blood $\mathrm{pH}$ of a malaria patient may cause tissue hypoxia by increasing blood oxygen affinity. 


\section{REFERENCES}

1) Abdalla, S., Weatherall, D. J., Wickramasinghe, S. N. and Hughes, M. (1980): The anaemia of $P$. falciparum malaria, Br. J. Haematol., 46, 171-183

2) Bellingham, A. J., Detter, J. C. and Lenfant, C. (1971): Regulatory mechanisms of hemoglobin oxygen affinity in acidosis and alkalosis, J. Clin. Invest., 50, 700-706

3) Bruce-Chwatt, L. J. (1980): Essential Malariology, Heinemann, London

4) Büngener, W. (1979): Weitere Beobachtungen über den Verlauf der Plasmodium berghei-Infektion in der Maus, Tropenmed. Parasitol., 30, 24-34

5) Chapman, A. G., Fall, L. F. and Atkinson, D. E. (1971): Adenylate energy charge in Escherichia coli during growth and starvation, J. Bacteriol., 108, 1072-1086

6) Darling, R. C. and Roughton, F. J. W. (1942): The effect of methemoglobin on the equilibrium between oxygen and hemoglobin, Am. J. Physiol., 137, 56-68

7) Devakul, K., Harinasuta, T. and Reid, H. A. (1966): ${ }^{125}$ I-Labelled fibrinogen in cerebral malaria, Lancet, ii, $886-888$

8) Donno, L. (1974): Antifolic combinations in the treatment of malaria, Bull. WHO, 50, 223-230

9) Ferraroni, J. J. and Speer, C. A. (1982): Fansidar prophylaxis, therapy, and immune response in rodent malaria (Plasmodium berghei), J. Parasitol., 68, 609-615

10) Hall, A. P. (1977): The treatment of severe falciparum malaria, Trans. R. Soc. Trop. Med. Hyg., 71, 367-379

11) Homewood, C. A. (1977): Carbohydrate metabolism of malarial parasites, Bull. WHO, 55, 229-235

12) Homewood, C. A. and Neame, K. D. (1983): Conversion of glucose to lactate by intraerythrocytic Plasmodium berghei, Ann. Trop. Med. Parasitol., 77, 127-129

13) International Committee for Standardization in Haematology (1978): Recommendations for reference method for haemoglobinometry in human blood (ICSH Standard EP 6/2: 1977) and specifications for international haemoglobincyanide reference preparation (ICSH Standard EP 6/3: 1977), J. Clin. Pathol., $31,139-143$

14) Mairbäurl, H., Humpeler, E., Schwaberger, G. and Pessenhofer, H. (1983): Training-dependent changes of red cell density and erythrocytic oxygen transport, J. Appl. Physiol., 55, 1403-1407

15) Ohtomo, H., Hioki, A. and Yoshino, M. (1982): Pathological influence of hypoxia in mouse malaria, Jpn. J. Parasitol., 31 (suppl), 42

16) Pardridge, W. M. and Oldendorf, W. H. (1977): Transport of metabolic substrates through the bloodbrain barrier, J. Neurochem., 28, 5-12

17) Stone, W. J., Hanchett, J. E. and Knepshield, Maj J. H. (1972): Acute renal insufficiency due to falciparum malaria. Review of 42 cases, Arch. Intern. Med., 129, 620-628

18) Weidekamm, E., Plozza-Nottebrock, H., Forgo, I. and Dubach, U. C. (1982): Plasma concentrations of pyrimethamine and sulfadoxine and evaluation of pharmacokinetic data by computerized curve fitting, Bull. WHO, 60, 115-122

19) WHO (1980): The clinical management of acute malaria, WHO Regional Publications, South-East Asia Series, No. 9

20) Zwart, A., Buursma, A., van Kampen, E. J., Oeseburg, B., van der Ploeg, P. H. W. and Zijlstra, W. G. (1981): A multi-wavelength spectrophotometric method for the simultaneous determination of five haemoglobin derivatives, J. Clin. Chem. Clin. Biochem. 19, 457-463 


\section{ファンシダールによるマラリア感染治療後の \\ マウス血液酸素親和性の変動}

日置 敦巳 · 大友 弘士

抗マラリア薬ファンシダール投与後の，マラリア感染マウスにおける血液酸素親和性の変動につい て調べた。 5 週齢, 雄の ddY マウスにPlasmodium berghei NK65 感染赤血球 $10^{7}$ 個を腹腔内接種し, その 5 日後にファンシダール（スルファドキシン $20 \mathrm{mg} / \mathrm{kg}$ 体重，ピリメサミン $1 \mathrm{mg} / \mathrm{kg}$ 体重）を経 口投与したところ，33\%のマウスは治療の 1 2 日後に死亡したが67\%のマウスはファンシダール投与 後 7 日以上生存した。これらのマウスでは治療により parasitemia は低下し, 低血糖, 続いて高乳酸血 症も徐々に回復した。しかし, 血液中の総へモグロビン濃度は治療 2 日後に低下し, へモグロビン中 に占めるメトへモグロビンの割合は逆に増加した。血液の酸素親和性は治療翌日には低下を示した が，2 日後および 3 日後には著しく上昇した。この上昇は, 主として血液 $\mathrm{pH}$ の回復に起因するもの と考えられた。酸素運搬に有効な血液中のへモグロビン濃度と酸素親和性の変動から推察すると, 治 療後, 特にファンシダール投与 2 日後の血液酸素供給能はかなり低下しているものと考えられた。

岐阜大学医学部寄生虫学教室 